DOI https://doi.org/10.30525/978-9934-26-182-4-34

\title{
ДОСЛІДЖЕННЯ СТАНУ ЗАБЕЗПЕЧЕННЯ ЛІКАРСЬКИМИ ЗАСОБАМИ ДЛЯ ЛІКУВАННЯ І ПРОФІЛАКТИКИ РОЗЛАДІВ ОПОРНО-РУХОВОЇ СИСТЕМИ
}

\author{
Черкашина А. B. \\ кандидат фармачевтичних наук, \\ доиент кафедри соиіальної фармаџії \\ Національний фармацевтичний університет \\ Варнавська О. В. \\ здобувач вищої освіти \\ спеціальності 226 - Фармачія, промислова фармація \\ Національний фармацевтичний університет \\ Стоколос Н. А. \\ здобувач вищої освіти \\ спеціальності 226 - Фармащчія, промислова фармація \\ Національний фармачевтичний університет \\ м. Харків, Украӥна
}

Очікується, що в міру старіння світового населення і посилення факторів ризику неінфекційних захворювань, поширеність і негативний вплив захворювань опорно-рухового апарату зростатимуть [2].

Медична i соціальна значущість захворювань опорно-рухового апарату визначається значною поширеністю, хронічним прогресуючим перебігом, зростанням показників первинної захворюваності та інвалідності, значними прямими та непрямими економічними втратами, зниженням якості життя і скороченням ії̈ тривалості [1].

Аналіз даних міжнародного дослідження глобального тягаря захворювань (The Global Burden of Disease Study) дозволяє зробити висновок, що за останні 30 років біль у нижній частині спини перемістився з 13 позиції (1990р.) на 9 позицію (2019 р.). У свою чергу інші захворювання опорно-рухового апарату перемістилися 335 позиції (1990 р.) на 19 позицію (2019 р.) [5].

Ураховуючи дані дослідження за віковими категоріями, необхідно відзначити, що серед причини втрачених років здорового життя біль у нижній частині спини знаходиться на 7 позиції у віковій категорії 10-24 років і на 4 позиції у віковій категорії $25-49$ років [5]. 
Невчасні та/або неефективні підходи до лікування та реабілітації призводять до тимчасової втрати працездатності й інвалідності та, як наслідок, до збільшення прямих та непрямих витрат окремих домогосподарств і держави в цілому.

3 урахуванням актуальності обраної тематики метою нашої роботи стало дослідження стану забезпечення лікарськими засобами для лікування і профілактики захворювань опорно-рухової системи.

Об'єктом дослідження стали дані інформаційно-пошукової системи «Державний реєстр лікарських засобів України» і довідника «Компендіум 2021 - лікарські засоби» $[3,4]$.

Предметом дослідження став перелік зареєстрованих в Україні лікарських засобів для фармакотерапії захворювань опорно-рухової системи.

Під час дослідження були використані методи системного аналізу, маркетингового аналізу, а також метод описового та абстрактного моделювання й узагальнення.

Відповідно до анатомо-терапевтично-хімічної класифікації лікарські засоби, що впливають на опорно-руховий апарат належать до групи М [4].

За фармакологічними властивостями вони поділяються на:

- протизапальні та протиревматичні засоби - М01;

- засоби, що застосовуються місцево у разі суглобового болю - М02;

- міорелаксанти - М03;

- засоби, що застосовуються для лікування подагри - М04;

- засоби, що застосовуються для лікування захворювань кісток - М05;

- інші засоби, що застосовуються у разі патології опорно-рухового апарату - М09 [4].

Нами проведено аналіз зареєстрованих в Україні лікарських засобів, що впливають на опорно-руховий апарат (за виключенням міорелаксантів та засобів, що застосовуються для лікування подагри). На період дослідження (листопад 2021 р.) на фармацевтичному ринку України було виявлено 587 торгових найменувань, що входили до 4 фармакологічних груп.

Установлено, що група протизапальних та протиревматичних засобів $\epsilon$ найбільш чисельною і налічує 403 торгових найменування. До неї входять нестероїдні протизапальні та протиревматичні засоби (398 торгових найменувань), комбіновані протизапальні (протиревматичні) засоби (4 торгові найменування), а також специфічні протиревматичні засоби (1 торгове найменування).

Підгрупа похідних оцтової кислоти налічує 92 торгові найменування. Найбільша кількість аналогів серед диклофенаків (52 лікарських 
препаратів). Натомість групи етодолаку, ацеклофенаку та амтолметину представлені виключно імпортованими ліками. У цілому по групі 67 \% імпортованих препаратів.

Підгрупа оксикамів налічує 76 торгових найменувань. Найбільша кількість аналогів серед мелоксикамів (58 лікарських препаратів). Одночасно групи теноксикаму та лорноксикаму представлені виключно імпортованими препаратами. У цілому по групі 64 \% імпортованих лікарських засобів.

Підгрупа похідних пропіонової кислоти налічує 134 торгових найменування. Найбільша кількість аналогів серед ібупрофенів (71 лікарський препарат). У той же час групи кетопрофену та флурбіпрофену представлені виключно імпортованими ліками. У цілому по групі 75 \% імпортованих препаратів.

Підгрупа коксибів налічує 38 торгових найменування. Групи рофекоксибу та парекоксибу представлені виключно імпортованими ліками. У цілому по групі 82 \% препаратів імпортуються.

Група лікарських засобів, що застосовуються місцево у разі суглобового і м'язового болю налічує 120 торгових найменування. До неї входять нестероїдні протизапальні для місцевого застосування (53 торгових найменування), капсаїцин та подібні засоби (3 торгові найменування), препарати, що містять похідні саліцилової кислоти (5 торгових найменувань), а також інші засоби, що застосовуються місцево у разі суглобового і м'язового болю (59 торгових найменувань).

Група лікарських засобів, що впливають на кісткову структуру i мінералізацію налічує 43 торгові найменування. До неї входять бісфосфонати (38 торгових найменувань), бісфосфонати, комбінації (2 торгові найменування), а також інші засоби, що впливають на кісткову структуру і мінералізацію (3 торгові найменування). У цілому по групі $93 \%$ імпортованих препаратів.

Група інших засобів, що застосовуються у разі патології опорнорухового апарату налічує 21 торгове найменування. До неї входять ферменти (7 торгових найменувань), а також різні засоби, що застосовуються при патології опорно-рухового апарату (14 торгових найменувань). У цілому по групі 85 \% імпортованих препаратів.

Висновки. За результатами проведеного дослідження нами виокремлені активні речовини, які виготовляються значною кількістю виробників, в надлишковій кількості знаходяться на українському фармацевтичному ринку і створюють надмірну конкуренцію, а саме: диклофенак (76 торгових найменувань: 52 препарати-аналоги для системного застосування і 24 препарати-аналоги для місцевого 
застосування), мелоксикам (58 препаратів-аналогів для системного застосування), ібупрофен (75 торгових найменувань: 71 препаратіваналогів для системного застосування і 4 препарати-аналоги для місцевого застосування), декскетопрофен (36 препаратів-аналогів для системного застосування).

Також нами були проаналізовані тенденцій українського фармацевтичного ринку препаратів для лікування захворювань опорно-рухової системи і визначені групи препаратів, які є залежними від імпорту через недостатню кількість вітчизняних аналогів. Лікарські препарати підгрупи коксибів (М01АН), засоби, що впливають на структуру і мінералізацію кісток (М05В) і препарати підгрупи інших засобів, що застосовуються при патології опорно-рухового апарату (М09A) найбільше залежать від імпорту і мають ризики фізичної та економічної доступності.

\section{Література:}

1. Долгополов О. В., Полішко В. П., Ярова М. Л. Епідеміологія захворювань кістково-м'язової системи в Україні за період 1993-2017 pp. Вісник ортопедї, травматології та протезування. 2019. № 4. С. 101-108.

2. Захворювання опорно-рухового апарату $\epsilon$ основним фактором інвалідизації. Центр громадського здоров’я МОЗ України. 08.11.2020. URL: https://np.pl.ua/2020/11/zakhvoriuvannia-oporno-rukhovoho-aparatu-ieosnovnym-faktorom-invalidyzatsii-tshz/_дата звернення: 22.10.2021).

3. Інформаційно-пошукова система «Державний реєстр лікарських засобів України». Державний експертний центр Міністерства охорони здоров'я України. URL: http://www.drlz.kiev.ua (дата звернення: 01.11.2021).

4. Компендіум 2021 - лікарські засоби. URL: http://compendium.com.ua/ (дата звернення: 01.11.2021).

5. Global burden of 369 diseases and injuries in 204 countries and territories, 1990-2019: a systematic analysis for the Global Burden of Disease Study 2019. 17.10.2020. The Lancet. V. 396. P. 1204-1222. URL: https:// www.thelancet.com/journals/lancet/article/PIIS0140-6736(20)30925-9/fulltext (дата звернення: 22.10.2021). 